\title{
KNOWLEDGE OF NURSES IN THE USE OF ALTEPLASE: INTEGRATIVE REVIEW
}

\author{
Lucio da Silva Ferreira', Jefferson Carlos de Oiveira'2, Jaqueline Santos Viana 3 , Osias Ferreira Forte ${ }^{4}$, Doris \\ Franciscato5, Magda Rodrigues Leal6, Marcelo Marreira7
}

1- Nurse, Specialist in Teaching for Higher Education in Nursing, Professor at The University Center Anhanguera - Vila Mariana. São Paulo -SP, Master's degree from Anhanguera-Uniderp Pirituba University, São Paulo- SP- E-mail: Iuciossferreira@hotmail.com, Orcid: https://orcid.org/0000-0003-2381-0658

2- Nurse, Professional Master in Nursing in the Health Care Process by the São Camilo University Center, Professor of the Nursing course and Post-Graduation in Urgency and Emergency - Anhanguera University Center of São Paulo - Vila Mariana, Scientific Director Revista Saúde Coletiva, Assessor Cientifico Revista NURSING, Orcid- https://orcid.org/0000-0002-5258-7099

3- Nurse, Specialization in Obstetric Nursing, Specialization in Health Auditing. Academic Coordinator of the Anhanguera University Center of São Paulo- Vila Mariana, São Paulo- SP Orcid- https://orcid.org/0000-0002-5734-191X

4- Nurse, Specialization in Urgency and Emergency, Specialization in Auditing, Specialization in Auditing, Specialization in Hospital Administration, Specialization in Dermatological Nursing, Master in Health Sciences, by The State Public Server, São Paulo. Professor of the Nursing Course - Anhanguera University Center of São Paulo - Vila Mariana. Orcid https://orcid.org/0000-0002-8262-3513

5- Nurse, Specialization in Critical Care, Specialization in Teaching for higher education. Professor of the Nursing Course - Anhanguera University Center of São Paulo - Vila Mariana. Orcid https://orcid.org/0000-0003-0372-0292

6- Nurse, Specialization in Hospital Administration, Specialization in Obstetrics, Specialization in Collective Health with Emphasis on Family Health, Master in Health Sciences, by The State Public Servant, São Paulo. Professor of the Nursing Course - UNINOVE University- São Paulo, Professor UNISAN Centro Universitário Santa Rita, São Paulo-Orcid- https://orcid.org/0000-0003-1021-0696

7- Nurse, Specialist in Obstetric and Gynecological Nursing, ABC Medical School. Master in Biophonics Applied to Health Sciences, uninove and PhD student in Bioofotonic Applied to Health Sciences, uninove, Professor of the University Nove de Julho, Lasertherapist and acupuncturist. Orcid- https://orcid.org/0000-0002-5435-4301

Health professionals, especially nurses who follow the entire fibrinolytic therapy procedure, should be aware of the mechanisms of action of alteplase, especially its contraindications. Objective: To identify the knowledge of the nursing professional in the administration of the use of alteplase in urgency and emergency. Method: This is an Integrative Review, conducted from July to September 2019, the study included publications of scientific articles, selected and published from 2014 to October 2019, available electronically in full text, in Portuguese, English and Spanish in the aforementioned Latin American and Caribbean Literature in Health Sciences (LILACS), Scientific Electronic Library (SciELO), BDENF (Nursing Database), PUB (International Literature in Health Sciences) databases. Result: A total of 07 articles were part of this study. Identified in SciELO 05 articles in LILACS 02 articles. No articles were selected in BDENF and pubmed database according to eligibility criteria. The number of articles eligible for the research was 07 articles. Conclusion: The present study highlights the need for a targeted approach to the clinical practice of nurses addressing the need for clarification and training regarding the handling and knowledge of the use of Alteplase, opening precedents for future research.

Keywords: Myocardial infarction, Nurse, Alteplase.

2020 November Edition | www.jbino.com | Innovative Association 


\section{Introduction}

One of the main causes of mortality in adults refers to cardiovascular diseases (CVD) affecting both sexes worldwide, being considered one of the dominant causes in relation to premature deaths, occurring in $75 \%$ in low-income and middle-income countries. In relation to Brazil, there is a tendency to decline, but it is still considered one of the main causes of death in adults'. There is a decline observed in recent years in relation to cerebrovascular diseases, however, even with recent advances in clinical and interventional treatments, ischemic heart diseases caused 116,333 deaths in 2016, making up $80 \%$ related to acute presentations, consisting of acute myocardial infarction ${ }^{2}$. It is noteworthy that the World Health Organization (WHO) assumes that by 2030, the estimate reaches 23 million deaths from cardiovascular diseases ${ }^{3}$. The high prevalence of these diseases can be explained both by the increase in the age group of the population and by exposure to classically known risk factors such as inadequate eating habits, physical inactivity, smoking, alcoholism, increased prevalence of obesity, stress, in addition to socioeconomic factors ${ }^{4}$. In the midst of cardiovascular diseases, Acute Myocardial Infarction (AMI) represents an important public health problem in the world and in Brazil, presenting high incidence, prevalence and mortality rates ${ }^{2}$. Barbosa et al(2019), report that AMl can lead to death, and annually,7.4 million people may be affected 3 . Acute myocardial infarction (AMI), is currently considered an important public health problem in Brazil ${ }^{5}$. The majority of deaths caused by AMI occur in the first hours of disease manifestation, with $40 \%-65 \%$ of cases in the first hour and approximately $80 \%$ in the first 24 hours. Thus, most deaths from AMI occur outside the hospital environment, usually unassisted by physicians ${ }^{6}$. Changes started with the approval of the thrombolytic agent Alteplase, or recombinant plasminogen activator (rt-PA), but even with its proven efficacy, its treatment still represents challenges regarding its implementation, and its therapy ${ }^{7}$.

In this priori, the nursing practice with the patient with AMI becomes extremely relevant through the need for the management of care based on a field of specialized knowledge, since the nurse is required skills and competencies to provide individualized and holistic care ${ }^{8}$. Important advances have occurred in thrombolytic therapy, providing a decrease in the mortality of patients affected by infarction. It is worth mentioning, the role of the nursing professional in relation to the knowledge of thrombolytic drugs, because the handling, administration, and the presence of possible complications are often identified through the technical and scientific preparation of the nursing professional?.

However, nursing is responsible for the primary follow-up and provision of continuous care to its patients, based on institutional protocols, based on anamnesis, identification of alterations and monitoring of the parameters established among others ${ }^{10}$. In view of the above, the following northern question arises. What is 
the knowledge of nurses regarding the administration of alteplase? Therefore, the aim of this study was to identify the knowledge of the nursing professional in the administration of the use of alteplase in urgency and emergency.

\section{Method}

This is an integrative review, carried out from July to September 2019. The review of the process was based on the recommendations of the preferred reporting items for systematic reviews and meta-analyses ${ }^{11}$ (PRISMA) conference list. The Integrative Review refers to a method that allows the synthesis of multiple published studies enabling general conclusions about a particular area of study 12,13. The integrative review occurred in six stages: Phase 1 - Identification of the theme and hypothesis of research problem for the elaboration of the integrative review; Phase 2 - Establishment of criteria for inclusion and exclusion of studies found in the search for literature; Phase 3 Categorization of studies and data collection; Phase 4 - Evaluation of the studies included in the integrative review; Phase 5 - Interpretation and discussion of results; Phase 6 - Presentation of the integrative review. After delimitation, it was followed with the evaluation of the research problem and its stratification following the PVO strategy (Population / Problem, Variable and Results / Outcomes). The mnemonic PICO was applied to define the guide question: What is known by the nurse in the administration of alteplase? The searches were carried out in the databases the Latin American and Caribbean Literature on Health Sciences (LILACS), Scientific Electronic Library (SciELO), BDENF (Nursing Database) indexed the virtual health library, and pubmed (International Literature in Health Sciences). The study included the eligibility criteria, which included publications of scientific articles, selected and published from 2014 to 2029, available electronically in full text, in Portuguese, English and Spanish. We used the health terminology consulted in the Descriptors in Health Sciences (DeCS) and the Medical Subject Headings (MeSH), by which the respective descriptors were identified: alteplase AND NURSE, alteplase AND acute infarction, fibrinolytic AND acute infarction, nurse AND alteplase AND myocardial infarction. Repeated articles were excluded, those that even entering the search did not fit the theme, reviews, book chapters, dissertations or theses. An instrument adapted by the researchers was used for the analysis of methodological rigor that allowed the survey to be raised, containing mainly the following variables: Database, Parents of origin, Title, Type of study, Authors, Journal and year of publication. All selected articles were submitted to thorough reading, performed in two stages: in the first one, the synthesis of the identification data and the characterization of the sample were performed and, in the second, the analysis of the content of the articles, being validated by two researchers. 
Figure 1 - Flowchart of identification, selection and inclusion of studies of the integrative review of the literature. São Paulo, SP, 2020.

N. de relatos identificados no

banco de dados de buscas $=2750$

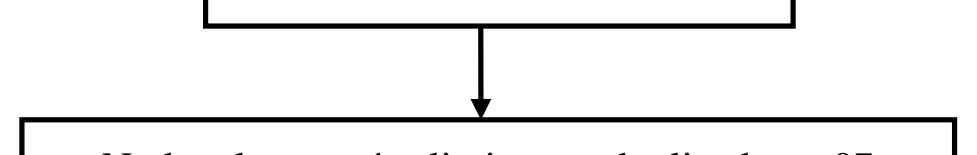

N. de relatos após eliminar os duplicados $=07$
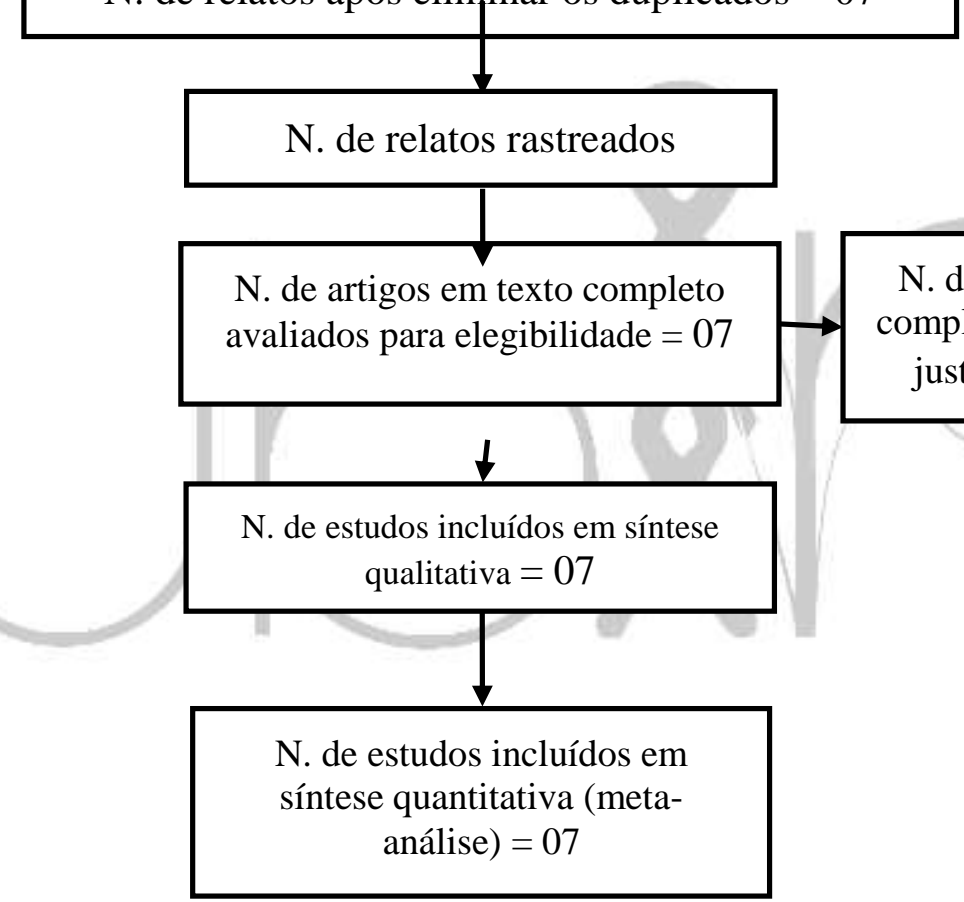

\section{Result}

Source: search data.

Table 1 shows the characterization of the main studies developed included in the integrative review through: Database, Parents of origin, Title, Type of study, Authors, Journal and year of publication, São Paulo- SP.

\begin{tabular}{|c|c|c|c|c|c|}
\hline Databases & $\begin{array}{l}\text { Parents of } \\
\text { origin }\end{array}$ & Title & Type of study & Authors & $\begin{array}{l}\text { Journal and year } \\
\text { of publication }\end{array}$ \\
\hline Lilacs & Brazil & $\begin{array}{l}\text { Fibrinolytics: } \\
\text { indications and } \\
\text { treatment of } \\
\text { bleeding } \\
\text { complications } \\
\end{array}$ & $\begin{array}{l}\text { Literature } \\
\text { review }\end{array}$ & $\begin{array}{l}\text { Baruzzi, Antonio } \\
\text { Cláudio do; } \\
\text { Stefanini, } \\
\text { Edson; Manzo, } \\
\text { Gianni }\end{array}$ & $\begin{array}{l}\text { Rev. Soc. Cardiol. } \\
\text { State of Sao Paulo; } \\
28(4): \text { : } 421-427, \\
\text { Oct.-Dec. } 2018 .\end{array}$ \\
\hline Scielo & Spain & $\begin{array}{l}\text { Streptoquinasa } \\
\text { a casi } 30 \text { años }\end{array}$ & $\begin{array}{l}\text { Literature } \\
\text { review }\end{array}$ & $\begin{array}{l}\text { Casola Crespo } \\
\text { Roberto, Casola }\end{array}$ & $\begin{array}{l}\text { Archivo Medical } \\
\text { Magazine de }\end{array}$ \\
\hline
\end{tabular}




\begin{tabular}{|c|c|c|c|c|c|}
\hline & & $\begin{array}{l}\text { demostrada su } \\
\text { eficacia en el } \\
\text { infarto agudo de } \\
\text { miocardio }\end{array}$ & & $\begin{array}{l}\text { Crespo Eugenio, } \\
\text { Castillo Sánchez } \\
\text { Gregorio, } \\
\text { Casola Barreto } \\
\text { Eugenio. }\end{array}$ & $\begin{array}{l}\text { Camaguey, AMC } \\
\text { vol.20 no.1 } \\
\text { Camagüey ene.- } \\
\text { feb. } 2016 .\end{array}$ \\
\hline Scielo & Uruguay & $\begin{array}{l}\text { Infarction agudo } \\
\text { de miocardio } \\
\text { lejos de los } \\
\text { centros de } \\
\text { hemodinamia, } \\
\text { percepción de la } \\
\text { calidad de vida } \\
\text { postratamiento } \\
\text { con fibrinolytics } \\
\text { y factors related }\end{array}$ & $\begin{array}{l}\text { Observational, } \\
\text { retrospective } \\
\text { study with } \\
\text { prospective } \\
\text { follow-up }\end{array}$ & $\begin{array}{l}\text { Moreira } \\
\text { Eduardo, Pintos } \\
\text { Nury, Arteaga } \\
\text { María De, } \\
\text { Negreira Sandra } \\
\text { Torres, Roza } \\
\text { Rita Da, } \\
\text { Albornoz Henry } \\
\text { et al. }\end{array}$ & $\begin{array}{l}\text { Rev. Urug. Cardiol. } \\
\text { vol.34 no.1 } \\
\text { Montevideo Apr. } \\
2019 .\end{array}$ \\
\hline Lilacs & Brazil & $\begin{array}{l}\text { Acute } \\
\text { myocardial } \\
\text { infarction with } \\
\text { ST supra: } \\
\text { thrombolysis at } \\
\text { any site where } \\
\text { medication is } \\
\text { available }\end{array}$ & $\begin{array}{l}\text { Literature } \\
\text { review }\end{array}$ & $\begin{array}{l}\text { Baruzzi, Antonio } \\
\text { Cláudio do } \\
\text { Amaral; } \\
\text { Stefanini, } \\
\text { Edson; Pispico, } \\
\text { Agnaldo. }\end{array}$ & $\begin{array}{l}\text { Rev. Soc. Cardiol. } \\
\text { State of Sao Paulo; } \\
28(4): 409-420, \\
\text { Oct.-Dec. } 2018 \text {. }\end{array}$ \\
\hline Scielo & Uruguay & $\begin{array}{l}\text { Fibrinolytics en } \\
\text { el infarction } \\
\text { agudo de } \\
\text { miocardio. } \\
\text { Análisis de una } \\
\text { cohorte } \\
\text { uruguaya en un } \\
\text { período de } \\
\text { cuatro años } \\
\end{array}$ & $\begin{array}{l}\text { Retrospective } \\
\text { observational } \\
\text { study }\end{array}$ & Frank Towers. & $\begin{array}{l}\text { Rev.Urug.Cardiol. } \\
\text { vol.32 no.2 } \\
\text { Montevideo Aug. } \\
2017\end{array}$ \\
\hline Scielo & $\begin{array}{l}\text { Buenos } \\
\text { Aires- } \\
\text { Argentina }\end{array}$ & $\begin{array}{l}\text { Acute coronary } \\
\text { syndromes }\end{array}$ & $\begin{array}{l}\text { Prospective } \\
\text { and } \\
\text { multicenter } \\
\text { cardiovascular } \\
\text { intensive care } \\
\text { units }\end{array}$ & $\begin{array}{l}\text { De Abreu } \\
\text { Maximiliano, } \\
\text { Natalia } \\
\text { Vensentini, } \\
\text { Javier Mariani, } \\
\text { Juan Gagliardi, } \\
\text { Doval Hernán, } \\
\text { Carlos Tajer. } \\
\end{array}$ & $\begin{array}{l}\text { Medicine (B. Aires) } \\
\text { vol. } 79 \text { no.6 } \\
\text { Autonomous City of } \\
\text { Buenos Aires Dec. } \\
2019\end{array}$ \\
\hline Scielo & Venezuela & $\begin{array}{l}\text { Caracterización } \\
\text { del infarto agudo } \\
\text { de miocardio en } \\
\text { pacientes } \\
\text { treated at } \\
\text { Ezequiel } \\
\text { Zamora Integral } \\
\text { Diagnostic } \\
\text { Medical Center } \\
\text { in Venezuela }\end{array}$ & $\begin{array}{l}\text { Serial study of } \\
34 \text { patient } \\
\text { cases }\end{array}$ & $\begin{array}{l}\text { Batista } \\
\text { González } \\
\text { Marilina, } \\
\text { Escalona } \\
\text { Ballester } \\
\text { Yurisván. }\end{array}$ & $\begin{array}{l}\text { Integral Diagnostic } \\
\text { Medical Center, } \\
\text { ccm. Ezequiel } \\
\text { Zamora of } \\
\text { Venezuela. ccm } \\
\text { [Internet]. vol.19 } \\
\text { no. } 4 \text { Holguín oct.- } \\
\text { dic. } 2015 .\end{array}$ \\
\hline
\end{tabular}

Source: author, 2020.

\section{Discussion}

Fibrinolytics are molecules that activate plasminogenics in plasmin, which act directly on the fibrin present, no clot disfacing or thrombus 14, 15, 19. About 20 years ago I studied Fibrinolytc Therapy Trialist Collaborative (FTT), observed a reduction in mortality between $1825 \%$ after the first six hours from the start of AMI in 1000 patients, during the infusion of fibrinolytics. Ou seja, or the succession of fibrinolytic therapy is related to early infusion of the drug.14,15, 16, 17, 18, 21. A strategy of reperfusion is aimed at saving 
or maximizing myocardial cells, while also reducing the mortality of two patients with hair attack AMI.15 The benefits originating from this strategy are very important, because there is a better ventricular function, a favorable modification of the ventricular remodeling process, an electrical instability (arrhythmias), a greater opening of collateral circulation networks 15,17,18. O Hemorrhagic Cliff is one of the main complications, both fibrinolytic, sendo or intracranial or with higher mortality. Or control pressure and or accompanying collagulopathy should be checked, apart from contraindications $14,18,21$. Or intracranial bleeding is more prevalent after the first 24 hours after the start of the Alteplase infusion, and should be done for those patients with poor neurological status. According to the authors, the hemorrhagic events that can occur without treatment, can be reversed, with the administration of platelets, antifibrinolytics and blood concentrate14. Due to the recent occurrence of the event, lack of training, inexperience of the emergency services team or prognosis, the patient ends up being compromised. For this reason, there is a need for training and training of teams to help them save this space14,17.

For fibrinolytic therapy to be achieved or successful, the first attention to the AMI victim needs to be quick and objective. Identify patients with thoracic disease and carry out a 12-lead electrocardiogram, first and foremost ações to serem adados with disease, to initiate the diagnosis and consequently or initial management of this patient. The time elapsed between the identification of the patient as the patient and the performance of the electrocardiogram should not exceed twenty minutes15,17, 18, 20. Know the absolute contraindications, such as a history of Cerebral Vascular Accident less than six months, neoplasms, traumas or surgeries recents with less than three weeks, history of gastrointestinal bleeding with menstrual excess, punctures not compressed within the last 24 hours, primary and must be questioned before the start of treatment 15, 18. Meanwhile there are relative contraindications such as transient ischemic accident or recurrent last six months, oral anticoagulant treatment, gestation in the first week after delivery, refractory hypertension (systolic pressure greater than $180 \mathrm{mmHg}$ and diastolic pressure greater than $110 \mathrm{mmHg}$, advanced liver disease, infectious endocarditis, history of peptic ulcer, prolonged cardiopulmonary resuscitation, levied in consideration mainly due to the cliff of Bleeding 15, 18. Initiated or treatment, or nurse will observe or disappear of the giver that will occur within minutes after or start of infusion, independent of administration of analgesics 16. Regression of nonelectrocardiogram ischemic alterations, mainly of the ST segment and reversal of the T wave with more than $50 \%$ of the isoelectric line, due to reperfusion of compromised artery at the first hour after the start of treatment16, 18. Cardiac monitoring should not be interrupted because this There are arrhythmias that may occur may indicate that the treatment is running satisfactorily, due to or restoration of coronary flux 15,18 . In many 
patients or acute restoration of coronary flux it can trigger a transient sinus bradycardia followed by hypotension, logo or hemodialysis state. Monitored at all times 15, 18. Given the importance of quick and objective attention, the need for organization, training and dissemination of two acquired knowledge is envisaged for a multiprofissional emergency team. E a patient guidance for the rapid recognition of two symptoms suggestive of AMI17.

\section{Conclusion}

The study consented to understand the knowledge that nurses working in a unit specialized in acute myocardial infarction have about the use of Alteplase to treat acute myocardial infarction. Through the benefits of medication, a limitation is pointed to its use, however the care of patients with acute myocardial infarction is seen as a medical emergency. Thus, it is believed that the knowledge of the investigated reality contributes to the construction of nursing knowledge, assisting nurses in the field of cardiology that provides direct care to these patients, deepening knowledge and decisionmaking improving clinical practice. In this perspective, it is necessary to need an approach directed to the clinical practice of nurses addressing the need for clarification and training regarding the handling and knowledge of the use of Alteplase, opening precedents for future research and studies in relation to the proposed theme.

\section{Reference}

1-Alves Leonardo, Polanczyk Anne Carisi. Hospitalization for Acute Myocardial
Infarction: A Population-Based Registry. Arq. Bras. Cardiol. [Internet]. [cited 2020 Oct 08]. Available from: http://www.scielo.br/scielo.php?script=sci_ arttext\&pid=S0066-

$782 \times 2020005012201 \& \operatorname{lng}=e n$. In press 2020. Epub Sep 21, 2020. https://doi.org/10.36660/abc.20190573.

2-Oliveira Gláucia Maria Moraes de, Villela Paolo Blanco. The Importance of the Prehospital Phase in ST Elevation Myocardial Infarction. Arq. Bras. Cardiol. [Internet]. 2018 Oct [cited 2020 Oct 08] ; $111(4$ ): 594-595. Available from: http://www.scielo.br/scielo.php?script=sci_ arttext\&pid=S0066-

$782 \times 2018001600594 \&$ lng $=e n$.

https://doi.org/10.5935/abc.20180209, .

3-Barbosa NO, Santos MR, De Oliveira RW, Fernandes VS, Naziazeno SDS. Hospitalization profile of patients with Acute Myocardial Infarction in the State of Sergipe, between 2014 and 2018. 2nd International Nursing Congress - $\mathrm{ClE} / 13^{\circ}$ Unit Nursing Day (JEU) - May 6-10, 2019, v. 1, n. 1 (2019).

4-Vaz DWN, Rezende RWS, Barros TVL, Atta JFM, Santos Filho LC, Miranda TLKS. Epidemiological description of patients hospitalized with $\mathrm{AMI}$ in the State of Pará (from 2015 to 2019). Rev Bra Edu Health. 2020, 10(1): 45-50.

5-Vaz J, Abelin AP, Schmidt MM, De Oliveira PP, Gottschall CAM, Rodrigues CG, De Quadros AS. Creation and implementation of a prospective and multicentric database of patients with 
Acute Myocardial Infarction: RIAM. Arq Bras Cardiol. 2020; 114(3):446-455.

6-Avezum JRA, Feldman A, Carvalho AC, Sousa AC, Mansur ADEP, Bozza AE, et al. V Guideline of the Brazilian Society of Cardiology on acute myocardial infarction treatment with ST segment elevation. Arq Bras Cardiol. 2015; 105(2 Suppl 1):1-105.

7-Maniva Samia Jardelle Costa de Freitas, Freitas Consuelo Helena Aires de. Use of alteplase in the treatment of acute ischemic stroke: what do nurses know? Rev. bras. sick. [Internet]. 2012 June [cited 2020 Oct 08] ; 65( 3 ): 474-481. Available from:

http://www.scielo.br/scielo.php?script=sci arttext\&pid=S0034-

$71672012000300012 \&$ lng $=e n$.

https://doi.org/10.1590/50034-

71672012000300012 .

8-Lobiondo-Wood G, Haber J. Nursing research: methods, critical evaluation and use. 4. Ed. Rio de Janeiro: Guanabara Koogan; 2001.

9-Rocha, Alessandra Bongiovani Lima; Oliveira, Celina Kina of; Oliveira, Renata Lourenzen de; Silva, Sandra Cristine da. Nursing (Säo Paulo); 3(23): 20-4, Apr. 2000.

10-Lima $M$, de-Oliveira-dos-Santos $M$, Cavalcante-Guedes M. Nursing clinical care for stroke patients using thrombolytics. UFPE On Line Nursing Journal [Internet]. 15 November 2013; [cited on 8 October 2020]; 7 (11): 6624- 6631. Available from: https:

periódicos.ufpe.br/revistas/revistaenferma gem/article/view/12317
11-Preferred Reporting Items for Systematic Reviews and Meta-Analyses (PRISMA). Available in: http://www.prismastatement.org. Accessed August 1, 2016.

12-Crossetti MGO. Integrative review of research in nursing the scientific rigor that is required [editorial]. Rev Gaúcha Enferm. 2012 Jun; 33(2):8-9.

13-Mendes KDS, Silveira RCCP, Galvão CM. Integrative review: research method for the incorporation of evidence in health and nursing. Text Context Sick. 2008 OctDec; 17(4):758-64.

14- Baruzzi, Antonio Cláudio do, Edson Stefanini, and Gianni Manzo. "Fibrinolytics: indications and treatment of bleeding complications." Rev. Soc. Cardiol. State of Sao Paulo (2018): 421-427.

15- Casola R, Casola E, Castillo G, Casola E. Estreptoquinasa a casi 30 años demostrada su eficacia en el infarto agudo de miocardio. AMC [Internet]. 2016 [consulted 21/01/2019];20(1):96-107. Disponible en: Disponible en: http://revistaamc.sld.cu/index.php/amc/a rticle/view/4170/2288

16-Moreira Eduardo, Pintos Nury, Arteaga María De, Negreira Sandra Torres, Roza Rita Da, Albornoz Henry et al. Acute infarction de miocardio lejos de los centros de hemodinamia, percepción de la calidad de vida postratamiento con fibrinolytics y factors related. Rev.Urug.Cardiol. [Internet]. 2019 Apr [cited 2020 Oct 14] ; 34( 1 ): 108-130. Available in: http://www.scielo.edu.uy/scielo.php?script $=$ sci_arttext\&pid $=$ S1688-

2020 November Edition | www.jbino.com | Innovative Association 
04202019000100108\&lng=es.

Http://dx.doi.org/10.29277/cardio.34.1.9

http://dx.doi.org/10.29277/cardio.34.1.9.

17- Baruzzi, Antonio Cláudio do Amaral, Edson Stefanini, and Agnaldo Pispico. "Acute myocardial infarction with ST supra: thrombolysis at any site where medication is available." Rev. Soc. Cardiol. State of Sao Paulo (2018): 409-420.

18- Torres, Frank. "Fibrinolytics en el infarction agudo de miocardio. Análisis de una cohorte uruguaya en un período de cuatro años." Uruguaya Journal of Cardiology 32.2 (2017): 121-131.

19- Souza, Cristiano Freitas de, et al. "Morphological and tissue characterization of culprit lesions in patients with acute myocardial infarction with ST-segment supraleveling after fibrinolytic use. Analysis with intracoronal ultrasound and iMAP technology®." Brazilian Journal of Invasive Cardiology 22.3 (2014): 225-232.

20-Meier, Pascal; Lansky, Alexandra J; Baumbach, Andreas Acute Coronary Syndromes Revista Uruguaya de Cardiología, vol. 29, number. 3, diciembre, 2014, pp. 380-390 Sociedad Uruguaya de Cardiología Montevideo, Uruguay.

21-Batista González, Marilina, and Yurisván Escalona Ballester. "Caracterización del infarto agudo de miocardio en pacientes assisted in The Integral Diagnostic Medical Center Ezequiel Zamora de Venezuela." Correo Scientific Physician 19.4 (2015): 680689. 